\title{
AUGUSTO ÓPẼ DA SILVA: UM LÍDER GUERREIRO E DISPOSTO
}

ILINIR JACINTO ${ }^{1}$

$\mathrm{Na}$ época quando o seu Augusto iniciou a luta pelo seu povo eu ainda era... como posso dizer... Eu era criança ainda, né? Então, a gente, na época, quando ele começou, a gente via o trabalho que ele fazia dentro da comunidade: Como organizar a comunidade, como pensar pelo futuro das novas gerações daquela época e também como conquistar mais espaço. Tudo isso a gente via a forma como ele se organizava. Eu lembro, naquela época, eu tinha dez anos, né... Então, eles se organizavam com as suas equipes, naquela época. E os tempos foram passando, foi quando eles conquistaram o novo espaço para sua comunidade, com a sua comunidade organizada. Foi uma luta. E uma luta muito, assim, na época bem... Era bem mais sofrido pra eles, em termos de, junto ao município, porque o preconceito era muito grande naquela época. Então, poucos apoios do município em relação à comunidade, quando seu Augusto era Liderança, naquela época. $E$ depois os tempos foram passando e eu também me interessei de também começar a participar de algumas reuniões de Lideranças, internas. Na época, o Augusto, ele era bem mais aberto com a comunidade, muita juventude naquela época participava. Aí, abriu esse espaço e a gente foi aprendendo com ele, até a gente se mudar pra cima. E eu comecei a participar mais... Então, na verdade, eu aprendi bastante com ele para depois também lutar pelo mesmo povo que ele lutou. Então, a gente sentiu muito quando ele... Quando nós perdemos ele, quando nós perdemos o seu Augusto, né? Mas, infelizmente, chegou o dia, não poderíamos fazer nada, né? Então, a gente também já

\footnotetext{
${ }^{1}$ Vice-diretor da Escola Estadual Indígena Nãn Ga. Liderança da Comunidade Indígena Kaingang de Iraí. E-mail: ilinir@yahoo.com.br .
} 
tinha aprendido alguma coisa - como lidar com o povo, como lutar com as instituições do governo, né, isso também ele nos ensinou bastante, inclusive o cacique atual. E assim por diante, né? Participamos juntos pelo Augusto, né, alguns movimentos. Então, ele teve o seu bom exemplo na nossa comunidade para organizar o seu povo, trazer a juventude pra interessar, pra lutar pelo seu povo. Então, a gente... Eu, pessoalmente, aproveitei essa oportunidade pra aprender coisas que eu não sabia para como lidar com as autoridades não indígenas e foi uma época muito ruim quando eles começaram o início, né? $O$ início do movimento sobre a terra. Pra depois... Porque o melhoramento da comunidade foi a partir de 92 . Começaram a conquistar o espaço maior para a comunidade de Iraí. Não lembro muito bem daquela época, antes de 92 não sei quantas famílias tinha. E foram muito sofridos naquela época. Era uma população, naquela época, que era menos atendida do município, naquela época. E ainda criticavam, para tirar a comunidade, né; o município tinha esse interesse de tirar essa comunidade para levar para Nonoai. Então, as Lideranças, naquela época, eles foram muito guerreiros pra superar esse sofrimento, esse preconceito, essa discriminação e vencer, né, até conquistar um espaço para o seu povo. Então, o Augusto era bem-visto na comunidade. É uma pessoa que não media esforço para buscar benefício pela sua comunidade, para lutar pelo seu povo. Era um homem, assim, disposto, né? Mesmo que ele não fazia parte mais da equipe de Liderança local, não fazia parte, né, mas ele, mesmo assim, nunca deixava de visitar as Lideranças, cacique, naquela época. Não deixava de visitar o grupo deles que fazia parte da Liderança. E ele sempre ajudava e sempre estava disposto quando a Liderança precisava dele pra buscar, assim, falar sobre terra, ele era o cara que mais se colocava pra falar, pra discutir sobre terra, né? Então, ele... A gente também, depois que ele morreu... Inclusive até eu mesmo, foi um dia que eu fui na casa do cacique. Falei para ele que agora a gente tem que começar a se organizar nós mesmos, porque a pessoa que veio organizando não existe mais, né? Então, depois da morte dele fui até o cacique, para as Lideranças dele, disse pra ele que nós não vamos parar, né? Mas vamos ter que começar a se abraçar mais e tocar em frente, pois ele se foi, mas a luta não pode parar, vamos ter que dar continuidade. E ele, na época, quando antes de ele morrer, ele sempre 
falava, né, que uma hora a gente vai ter que... Não vai existir mais. Ele mesmo falava. E alguém tem que dar continuidade. E é isso que eu fiz. Depois que ele foi, fui na Liderança, conversei com eles que vamos ter que continuar, se organizar mais. Então, isso é o que eu posso falar do seu Augusto. É claro que a gente sente a falta dele, mas isso, a falta dele, tem que nos fortalecer, a nossa luta... Tem que fortalecer, ficar mais forte com isso, não desanimar. A nova juventude está aí, a futura geração está aí, né? E temos que lutar por eles. Porque, hoje, a nossa comunidade é a menor do Rio Grande do Sul, pra isso a gente tem que lutar mais. A parte dele, ele já fez, o seu Augusto, e hoje não existe mais. Então, daqui pra frente temos que fazer. É o nosso dever de fazer, se nós não fizer, nós não temos a capacidade que ele teve. Então, isso é o nosso dever agora, que estamos agora liderando a nossa comunidade, né? Que hoje, a nossa terra é uma das pequenas, está aumentando cada vez mais as famílias, né, então fomos buscar espaço pra botar essas novas famílias que estão vindo, essas novas gerações que estão vindo e nós temos que se preocupar agora com um espaço maior. Então, era isso que eu tenho a falar do seu Augusto. 